\title{
Electrical and Electrochemical Properties of Sandwich- and Monolithic-Structured Dye-Sensitized Solar Cells with Various Counter Electrode Materials
}

\author{
Ellyse Oktaviani ${ }^{1}$, Natalita M. Nursam ${ }^{2,}{ }^{*}$, Shobih ${ }^{2}$, Jojo Hidayat $^{2}$, Lia M. Pranoto $^{2}$, Erlyta S. Rosa ${ }^{2}$, \\ Niki Prastomo ${ }^{1,3}$, Gerald E. Timuda ${ }^{4}$ \\ ${ }^{1}$ Department of Physics Engineering, Faculty of Engineering, Surya University, Tangerang, Banten - \\ Indonesia \\ 15143 \\ ${ }^{2}$ Research Center for Electronics and Telecommunication - Indonesian Institute of Sciences (LIPI), \\ Bandung - Indonesia 40135 \\ ${ }^{3}$ Department of Physics Engineering, Faculty of Engineering and Informatics, Universitas Multimedia \\ Nusantara, Tangerang, Banten - Indonesia 15811 \\ ${ }^{4}$ Research Center for Physics - Indonesian Institute of Sciences (LIPI), Tangerang Selatan, Banten - \\ Indonesia 15314 \\ *E-mail: natalita.maulani.nursam@lipi.go.id
}

Received: 10 May 2021 / Accepted: 1 July 2021 / Published: 10 August 2021

\begin{abstract}
A counter electrode is one of the crucial components in dye-sensitized solar cell (DSSC), where platinum, carbon composite, and poly(3,4-dioxythiophene)-poly(styrene sulfonate) or PEDOT:PSS are among the most widely used materials. In terms of configuration, DSSC is typically constructed in two ways: sandwich and monolithic. However, the DSSC performance associated with the selection of both counter electrodes and configuration has received little attention to date. This study aims to study the effect of counter electrode materials on DSSC performance by analyzing their electrical and electrochemical properties from their configuration standpoint. First, the physical properties of the counter electrodes materials were analyzed using scanning electron microscopy (SEM), followed by four-point probes, electrochemical impedance spectroscopy (EIS), incident photon-to-current conversion efficiency (IPCE), and current density-voltage (J-V) characterization. Among all variations, our results show that the sandwich-type DSSC with PEDOT: PSS counter electrode generated the best performance with a power conversion efficiency of $5.40 \%$, which was primarily attributed to the high conductivity $(3210 \mathrm{~S} / \mathrm{cm})$ and low charge transfer resistance $\left(R_{C E} 53 \Omega\right)$. It was also found that the electron transfer pathways that are determined by the cell configuration also had a significant impact on the cell performance.
\end{abstract}

Keywords: counter electrode; dye-sensitized solar cell; electrical and electrochemical properties; monolithic; sandwich 


\section{FULL TEXT}

(C) 2021 The Authors. Published by ESG (www.electrochemsci.org). This article is an open access article distributed under the terms and conditions of the Creative Commons Attribution license (http://creativecommons.org/licenses/by/4.0/). 